\title{
Post-treatment of Distillery Wastewater after UASB using Aerobic Techniques
}

\author{
N. Musee ${ }^{1 *}$, M.A. Trerise ${ }^{2}$ and L. Lorenzen ${ }^{1}$ \\ (1) Department of Process Engineering, Stellenbosch University, Matieland 7602, South Africa \\ (2) Jeffares \& Green (Pty) Ltd, P.O. Box 38561, Pinelands, 7430, South Africa (current address)
}

Submitted for publication: January 2007

Accepted for publication: May 2007

Keywords: wine distillery wastewater; UASB; anaerobic; aerobic; integration of treatment technique; pH control; hybrid system

\begin{abstract}
The treatment of high-strength wastewater from a distillery using grape-based feedstock was conducted through sequencing the upflow anaerobic sludge blanket (UASB) reactor and the aerobically-activated sludge reactors. The performance of the UASB system was evaluated at the end of a period of 33 days in terms of the final chemical oxygen demand (COD) removal. Final COD removal efficiency of up to $88.7 \%$ was achieved. The effect of varying the volumetric loading rates on COD removal was evaluated for the two experimental runs. For run I (undiluted), the volumetric loading rates ranged from 4.06 to $18.90 \mathrm{~kg} \mathrm{COD} / \mathrm{m}^{3}$.day and the maximum COD removal achieved by the reactor was $57.1 \%$. For experimental run II (diluted), the loading rates ranged between 3.60 to $8.20 \mathrm{~kg}$ $\mathrm{COD} / \mathrm{m}^{3}$.day, with the reactor achieving $88.7 \%$ COD removal. Post-treatment of the effluent using the aerobicallyactivated sludge reactor further improved the overall COD removal in run II to $96.5 \%$ and also reduced the phosphorous in the effluent to a final value of approximately $20 \mathrm{mg} / \mathrm{L}$. These experimental results indicate that sequential treatment of the distillery wastewater using UASB followed by aerobically-activated sludge treatment is an efficient system that makes the final effluent compliant with the requirements of environmental legislation.
\end{abstract}

\section{INTRODUCTION}

Brandy and spirits-related beverages are products of wine grapes from either low-quality wines or, in certain cases, as by-products of wine production. In recent years there has been a global upsurge in demand for brandy and spirits-related beverages from grape wine feedstocks. This triggered a rise in their production, which has resulted in the resurgence of problems related to the generation of large quantities of high-strength distillery wastewater (wastewater with very high organic content).

For instance, effluent sampled from three different distilleries in and around the Stellenbosch wine-growing area in South Africa was found to exhibit a high variance of organic load (in terms of chemical oxygen demand (COD)) of 30000 to 70000 $\mathrm{mg} / \mathrm{L}$ and low $\mathrm{pH}$ values of between 3 and 4 . These values were found to be similar to those previously reported by Wolmarans and De Villiers (2002), Moosbrugger et al. (1993) and Driessen et al. (1994). The large fluctuations in the characteristics of wine distillery wastewater can be attributed to the type of product generated, the type of feedstock used and the distillery-specific integrated waste management practices adopted. Therefore, such effluents present a serious challenge to the natural ecosystem and can cause considerable environmental problems if disposed without adequate treatment.

In general, several end-of-pipe effluent treatment technologies have been applied to treat effluent generated from agro-based industries. The thrust of applying such technologies is to eliminate or reduce any possible negative footprints of the effluent in the event of them entering the environment. In particular, examples of the treatment technologies that have been applied in treating grape-related effluents include constructed wetlands (Shepherd, 1998; Shepherd et al., 2001), woodlot irrigation (Marais, 2001; Chapman et al., 2001), anaerobic digestion systems (Calderon et al., 1998; García-Bernet et al., 1998; Danfonchio et al., 1998), aerobic digestion systems (Petruccioli et al., 2000; Petruccioli et al., 2002), evaporation ponds (Rankine, 1989), irrigation padlocks (Rankine, 1989) and rotating biological contractors (Müller, 1994; Malandra et al., 2003), to mention a few.

The most widely adopted technology in treating effluents containing high organic concentrations is the upflow anaerobic sludge blanket (UASB) reactor. The anaerobic digestive systems are favourable because of their low cost, operational simplicity and low production of solids. Moreover, the success of UASB lies in its capability to retain a high concentration of immobilised biomass because of the granulation of sludge particles (HulshoffPol, 1989). However, one important aspect when applying anaerobic processes in the treatment of effluents is to ensure careful operation and control, as well as efficient monitoring of convectional parameters such as $\mathrm{pH}$, alkalinity, temperature, organic load, etc.

The most common effluent characteristics that guide the design of effluent treatment technologies in agro-based industries are the high concentration of organic loads, high fluctuations in conductivity and, in certain cases, high variance in $\mathrm{pH}$ values. However, experience has shown that no single effluent treatment technique has the ability to target all the constituent components of the effluent that have the potential to exert negative environmental impacts if the effluent enters ecosystems such as rivers, underground water aquifers, dams, etc. Taking into account this inherent shortcoming of the individual technologies, we present in this

*Corresponding author: e-mail: nmusee@sun.ac.za [Fax: +27-21-808 2059]

Acknowledgements: The authors acknowledge THRIP, Winetech and NRF for financial support.

S. Afr. J. Enol. Vitic., Vol. 28, No. 1, 2007 
paper the results of treating distillery wastewater using an anaerobic process, followed by an aerobic post-treatment process. The thrust of introducing a hybrid treatment system, even though UASB is an established technology for treating agro-based effluents, was because of its inability to treat high-strength distillery effluent to a standard that meets the stringent South African environmental legislation (Müller, 1999).

\section{MATERIALS AND METHODS}

\section{Characteristics of distillery wastewater}

The characteristics of the distillery wastewater generated by various processes differ considerably. This is because the final distillery effluent is a function of the feedstock used as well as the waste management philosophies adopted by individual distillery plants. In this paper, we report the results of raw distillery effluent characteristics obtained from a plant specialising in producing neutral spirits in the Western Cape area of South Africa using wine grapes as feedstock. The parameters in this study included $\mathrm{pH}$, COD, organic nitrogen, TDS, conductivity, TSS, phosphorus, etc., which were determined using the Standard Methods (APHA, 1992). A summary of the characteristics of the raw distillery wastewater obtained from this study is given in Table 1 .

Apart from the effluent composition reported in Table 1, the distillery effluent also contained high levels of total phenols, as the feedstock was grapes. Moreover, the concentrations of the phenol pigments were much higher in effluents where the feedstock was red grape cultivars. The presence of the phenol pigments in the distillery effluent poses difficulties for the UASB treatment technology, as it cannot handle them adequately, thus justifying the incorporation of post-treatment of the effluent using an aerobic process. In a number of effluent streams, where the experimental samples were drawn for laboratory testing, the temperatures of these effluents ranged from $80^{\circ} \mathrm{C}$ to $90^{\circ} \mathrm{C}$.

\section{UASB reactor}

Effluents generated from the distillery were treated in two-stage anaerobic-aerobic biological systems. The UASB setup had been previously developed by Wentzel et al. (1985) for the purpose of treating winery effluent. A schematic representation of the labo-

\section{TABLE 1}

Some examples of the characteristics of effluent from a distillery using grape feedstock.

\begin{tabular}{lcc}
\hline Parameter & Parameter range & Mean values \\
\hline $\mathrm{pH}($ ratio) & $3.50-4.00$ & $3.76 \pm 0.08$ \\
$\begin{array}{l}\text { Conductivity }(\mathrm{mS} / \mathrm{m}) \\
\text { Chemical oxygen demand }\end{array}$ & $400-700$ & $531 \pm 115.18$ \\
(COD) (mg/L) & $35,667-42,183$ & $39,467 \pm 6869.45$ \\
Total dissolved solids & & \\
(TSS) (mg/L) & $10,184-16,123$ & $11303 \pm 223.44$ \\
Total suspended solids & & \\
(TSS) (mg/L) & $2095-2512$ & $2231 \pm 130.50$ \\
Organic nitrogen & & \\
(TKN) (mg/L) & $560-834$ & $93.83 \pm 9.40$ \\
Ammonia (mg/L) & $80.30-120.00$ & $979.03 \pm 62.95$ \\
Potassium (mg/L) & $373.63-1106.00$ & $191.75 \pm 11.30$ \\
Phosphorous (mg/L) & $177-98-215.00$ & \\
\hline
\end{tabular}

ratory-scale UASB reactor is shown in Figure 1. The reactor was constructed using a cylindrical Perspex glass column with a height and internal diameters of $120 \mathrm{~cm}$ and $10 \mathrm{~cm}$ respectively, and an effective internal volume of approximately $9 \mathrm{~L}$.

The effluent was pumped into the UASB reactors, and key parameters such as $\mathrm{pH}$, TSS, COD, nutrients and other components were adjusted to the desired levels to facilitate effective anaerobic effluent treatment. The reactor had a flat bottom with four evenly distributed inlet ports for the purpose of discharging the effluent in a horizontal direction. It was also equipped with 11 sampling ports that were evenly distributed along its vertical length, and a gas/liquid/solid separator was located at the top. In this experiment, gas collection was done using a hollow, inverted cone, although no gas flow-rate measurements were taken. The effluent was discharged through an annular space between the gas collection cone and a small solid/liquid separator of approximately $500 \mathrm{~mL}$ in volume.

The clarified effluent flowed over a v-shaped weir (launder) to the collection vessel, while the solids settled and were discharged back into the reactor under the force of gravity. The homogeneity of the fresh effluent was maintained through continuous mixing using a magnetic stirrer before it was fed into the inlet of the first UASB reactor.

\section{Aerobic biological treatment}

The batch aerobic experiments were conducted to determine the aerobic post-treatability of distillery wastewater following anaerobic treatment. This was to ensure that the final effluent meets the stringent discharge standards. Experiments were conducted by means of activated sludge systems in $200 \mathrm{~mL}$ volumetric flasks. The samples used were $100 \mathrm{~mL}$ each. The batch aerobic reactors were continuously shaken for 10 days in a shaker at $20 \mathrm{rpm}$.

The temperature was fixed at $30^{\circ} \mathrm{C}$ by means of a thermostatic unit. As the distillery wastewater did not contain sufficient quantities of the microorganisms required for the aerobic degradation, an activated sludge seed taken from a winery and distillery effluent treatment plant was acclimatised to this substrate. After the completion of the acclimatisation process, several batch aerobic degradation experiments were carried out.

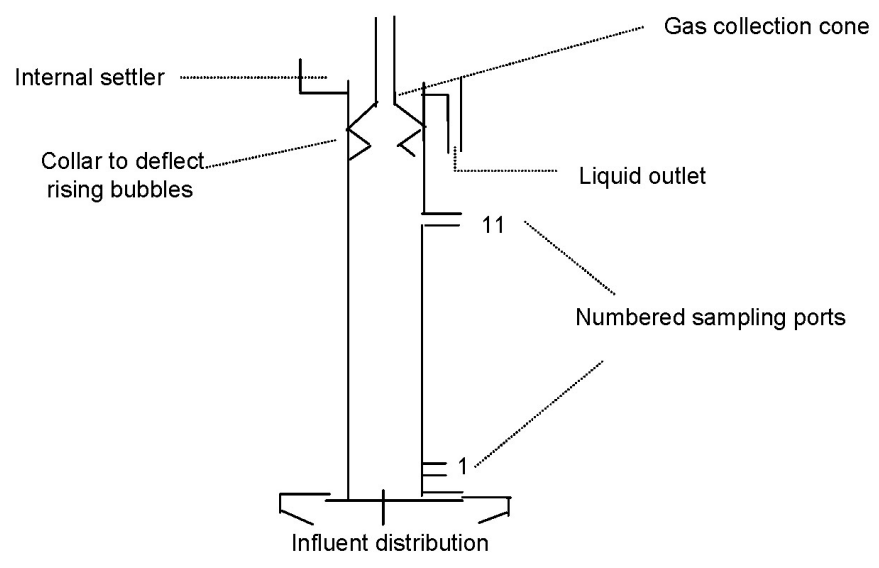

FIGURE 1

Schematic representation of laboratory-scale UASB reactor. 


\section{UASB system operation and feeding regime}

The entire experimental period lasted for 33 days after start-up and stabilisation, when four different experimental runs were carried out. These were characterised by different operating strategies, such as the loading rate and the quantity of COD contained in the filtered effluent (see Table 2). To initialise the laboratoryscale UASB reactor, it was inoculated with $3 \mathrm{~L}$ of soil seed sludge taken from a treatment effluent dam situated near one of the distilleries. No alterations were made to the seed sludge, as it contained microorganisms that were found to be suitable for the anaerobic degradation of the organic matter present in the distillery wastewater. The reactor was operated at a temperature of $35^{\circ} \mathrm{C}( \pm 1)$, controlled using a thermostat.

Since the anaerobic reactions are highly $\mathrm{pH}$ dependent, optimal UASB operations were achieved by maintaining the $\mathrm{pH}$ in the range of 6 to 8 over the entire experimental period. This was done by adding sodium hydroxide to gently shift the equilibrium to the desired range without disturbing the physical and chemical balance of the fragile microbial population (HulshoffPol, 1989).

Initially, a high volumetric loading rate of $9.13 \mathrm{~kg} \mathrm{COD} / \mathrm{m}^{3}$.day was used in experimental run I, and this was increased to a maximum of $18.9 \mathrm{~kg} \mathrm{COD} / \mathrm{m}^{3}$.day. However, the initial start-up was not successful. This may have been because the microorganisms in the sludge had not yet acclimatised, or due to the high feed rate.

Thus, in view of the poor COD reduction efficiency in experimental run I (undiluted), the experimental conditions were changed, particularly by varying the COD influent concentration and the volumetric loading rate per day (see Table 2). In the successive experiments (II - Phase 1 to II - Phase 3), the effluent loading rates were kept in the range of $4.06 \mathrm{~kg} \mathrm{COD} / \mathrm{m}^{3}$.day to $7.6 \mathrm{~kg} \mathrm{COD} / \mathrm{m}^{3}$.day via effluent dilution at certain ratios.

During experimental run II (diluted), lower volumetric loading rates were selected in order to allow the sludge bed to acclimatise and stabilise to the wastewater, with a corresponding constant flow rate of $2 \mathrm{~L}$ /day over the entire experimental period. However, the feed concentration was increased systematically up to $11400 \mathrm{mg} / \mathrm{L} \mathrm{COD}$ by the last day of the experiment, while the volumetric loading rate was increased to $7.6 \mathrm{~kg} \mathrm{COD} / \mathrm{m}^{3}$.day.

For the aerobic biological treatment, the initial inoculum used was soil seed that had been sourced from a nearby winery and distillery effluent treatment plant. For the aerobic reactor experiments, the effluent used was first treated in the anaerobic reactor. The effluent fed into the aerobic processes was characterised by COD values ranging from $1200 \mathrm{mg} / \mathrm{L}$ to $4000 \mathrm{mg} / \mathrm{L}$, as well as phosphorus and TKN with average concentrations of $75 \mathrm{mg} / \mathrm{L}$ and $366 \mathrm{mg} / \mathrm{L}$, respectively. The COD and phosphorus levels were monitored for a period of seven days, while the gallic acid was monitored at 24-hour intervals for three days.

\section{RESULTS AND DISCUSSION}

\section{UASB reactor performance}

In Table 3, a summary of the results obtained during the operational period for experimental runs I and II is provided. The values comprise the maximum, minimum, average and standard deviations for both influent and effluent for the two experimental runs. The performance of the laboratory-scale UASB reactor was examined over an experimental period of 33 days for both runs I and II. The changes in COD removal efficiencies, as well as the effect of the volumetric loading rates and the $\mathrm{pH}$ on COD removal, were then studied and reported.

\section{COD removal}

Figure 2 depicts the COD removal efficiencies as well as the COD concentrations for the influent and effluent under experimental run I. Initially, for the first 18 days, the COD removal efficiency was very low. Low efficiency values signify the inability of the anaerobic reactor to cope with the high variation of volu-

TABLE 2

The feeding regime of an anaerobic digester for 33 days.

\begin{tabular}{|c|c|c|c|c|}
\hline Experiment No. & $\begin{array}{l}\text { Feedstock COD } \\
\text { (filtered) }(\mathrm{mg} / \mathrm{L})\end{array}$ & $\begin{array}{l}\text { Flow rate } \\
\text { (L/day) rate }\end{array}$ & $\begin{array}{l}\text { Loading } \\
\text { (kg COD/m3.day) }\end{array}$ & Remarks \\
\hline I & 13700 & 2 & 9.13 & Initial start-up feedstock $1: 1$ \\
\hline II - Phase 1 & 6100 & 2 & 4.06 & Feedstock at 1:4 dilution \\
\hline II - Phase 2 & 9200 & 2 & 6.13 & Feedstock at 1:2 dilution \\
\hline II - Phase 3 & 11400 & 2 & 7.60 & Feedstock at $1: 1.5$ dilution \\
\hline
\end{tabular}

TABLE 3

Summary of operating results for the aerobic reactors during experimental runs I and II.

\begin{tabular}{|c|c|c|c|c|c|c|c|c|c|}
\hline \multirow[b]{2}{*}{ Parameter } & \multirow[b]{2}{*}{ Units } & \multicolumn{4}{|c|}{ Run I } & \multicolumn{4}{|c|}{ Run II } \\
\hline & & $\operatorname{Max}$ & Min & Avg. & Std. & $\operatorname{Max}$ & Min & Avg. & Std. \\
\hline $\mathrm{COD}^{\text {in }}$ (influent) & $\mathrm{mg} / \mathrm{L}$ & 28400 & 6100 & 14700 & 5300 & 12300 & 5500 & 9300 & 2050 \\
\hline COD $^{\text {out }}$ (effluent) & $\mathrm{mg} / \mathrm{L}$ & 16900 & 6100 & 11100 & 2400 & 7700 & 1290 & 3960 & 1710 \\
\hline COD removal & $\%$ & 57.10 & 0 & 13.60 & 41.33 & 88.70 & 24.00 & 54.17 & 21.00 \\
\hline Loading rates & $\mathrm{kg} \mathrm{COD} / \mathrm{m}^{3}$.day & 18.90 & 4.06 & 9.76 & 3.53 & 8.20 & 3.60 & 6.20 & 1.40 \\
\hline $\mathrm{pH}^{\text {in }}$ (influent) & No units & 7.85 & 3.86 & 7.29 & 0.67 & 7.00 & 7.85 & 7.40 & 0.22 \\
\hline $\mathrm{pH}^{\text {out }}$ (effluent) & No units & 8.00 & 5.36 & 6.66 & 0.83 & 5.57 & 8.00 & 7.06 & 0.73 \\
\hline
\end{tabular}


metric loading rates, ranging from 4.06 to $18.90 \mathrm{~kg} \mathrm{COD} / \mathrm{m}^{3}$.day, as well as the high COD concentration of the influent, which averages at $14700 \mathrm{mg} / \mathrm{L}$.

In the first four to five days of the start-up, the reactor had begun to achieve a certain level of equilibrium, although the removal efficiencies were low. However, after the fifth day, the erratic variation of volumetric loading rates, from $18.9 \mathrm{~kg}$ $\mathrm{COD} / \mathrm{m}^{3}$.day to $12.8 \mathrm{~kg} \mathrm{COD} / \mathrm{m}^{3}$.day within a day, and thereafter to lower values of around $5 \mathrm{~kg} \mathrm{COD} / \mathrm{m}^{3}$.day, destabilised the sludge bed. This caused the granules to be unstable, consequently leading to unsatisfactory COD removal results.

However, the process stabilised after the 18th day, although the COD removal efficiencies increased only slightly, to a maximum of $57.1 \%$. This can be attributed to the high loading rates, which ranged from 9.3 to $12.8 \mathrm{~kg} \mathrm{COD} / \mathrm{m}^{3}$.day. These values clearly were much higher than the values recommended by GarcíaBernet et al. (1998), namely $3 \mathrm{~kg} \mathrm{COD} / \mathrm{m}^{3}$.day for the start-up of anaerobic treatment of wine distillery wastewater.

Figure 3 shows the effect of the variation in COD concentration on the overall COD removal efficiency in experimental run II. During the first 10 days, which were phase 1 of experimental run II, the COD removal efficiency increased steadily from a value of
$20 \%$ to slightly above $50 \%$. This was an indication that the reactor adapted fairly well during the start-up period, and the concentration of the final treated effluent averaged around $4000 \mathrm{mg} / \mathrm{L}$.

Phase 2 of experimental run II lasted from the 11th to the 20th day. Between day 10 and day 13, there was a rapid variation in the influent COD concentration, ranging from $7100 \mathrm{mg} / \mathrm{L}$ to 9600 $\mathrm{mg} / \mathrm{L}$. This sudden load shock caused the removal efficiency to vary erratically between $56 \%$ and $43 \%$. Again, this was due to the disruption of the system equilibrium, which made the granules less effective in removing the COD from the influent. However, the reactor recovered after the 15 th day and its removal efficiency increased steadily up to $85 \%$ on day 20 . It is should be noted that the gap occurring between the 17th and 18th days was as a result of experimental disturbances.

In phase 3, the core objective was to establish the optimal influent concentration that the UASB reactor could handle efficiently. Thus, on day 21, the COD influent concentration was increased to about $11500 \mathrm{mg} / \mathrm{L}$. Likewise, and as expected, the performance became erratic and the COD removal efficiency dropped to about $30 \%$. Nevertheless, the system showed good recovery within the next five days, despite some fluctuations in COD influent concentrations, and it consequently adapted well to these

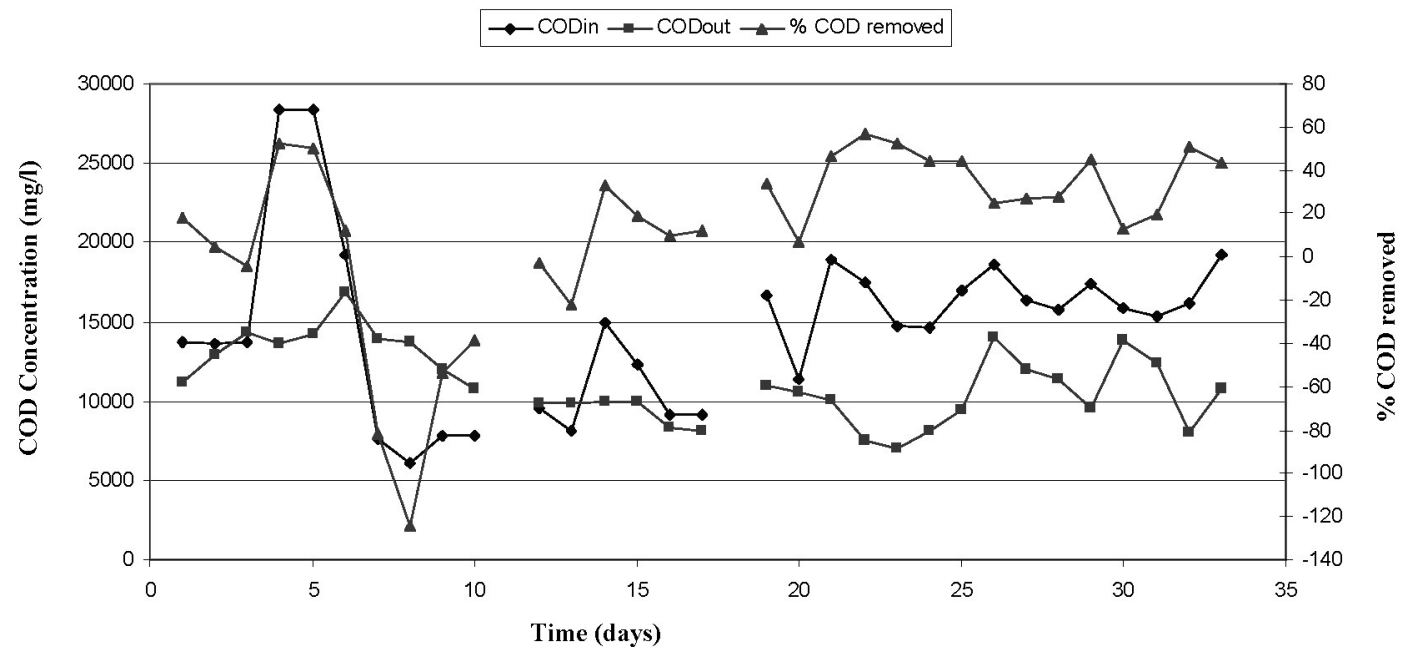

FIGURE 2

Changes in COD removal efficiency under run I.

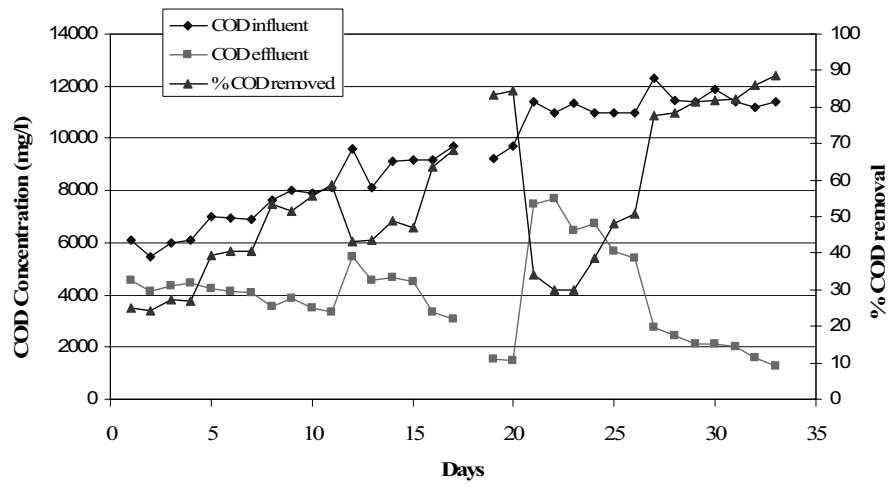

FIGURE 3

Changes in COD removal efficiency under run II.

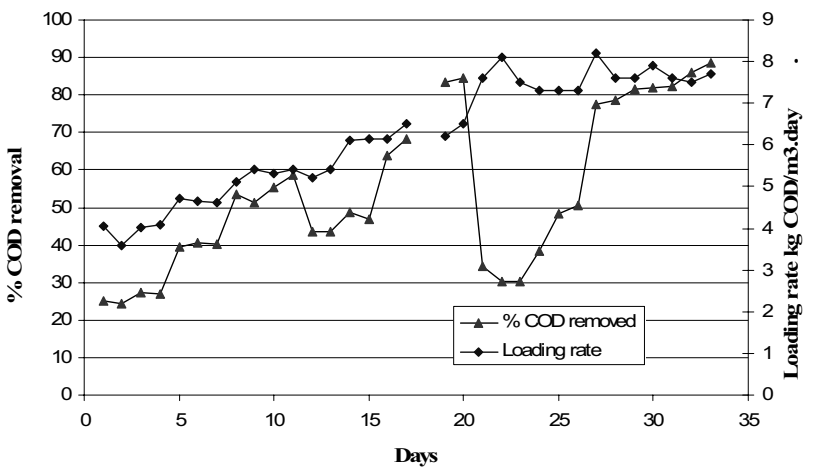

FIGURE 4

Volumetric loading rates vs. COD removal efficiencies under experiment II. 
operating conditions, giving rise to removal efficiencies ranging from $80 \%$ to $90 \%$. It is significant to note that, after the 26th day, the final treated effluent concentration was well below 3000 $\mathrm{mg} / \mathrm{L}$, although the influent concentrations were the highest in this entire experiment, averaging $11400 \mathrm{mg} / \mathrm{L}$. These results compare well with those for the treatment of distillery effluent previously reported in the literature by Wolmarans and De Villiers (2002), Eremektar et al. (1999) and Goodwin and Stuart (1994).

\section{Volumetric loading rates}

The effect of volumetric loading rates on COD removal efficiencies was studied and the results obtained, based on the experimental data from run II, are graphically presented in Figure 4. Under all the three phases under experimental run II, the COD removal efficiency appeared to track the variations in the volumetric loading rate. For instance, in phase 1, the COD removal efficiency increased steadily, tracking the increase in the volumetric loading rate from $4 \mathrm{~kg} \mathrm{COD} / \mathrm{m}^{3}$.day to $5.40 \mathrm{~kg} \mathrm{COD} / \mathrm{m}^{3}$.day. Thus, the process showed efficiency losses and gains corresponding to the sudden loading rate variations and the presence of good homogeneity in the reactor respectively.

In phase 2 , where the process dynamics were characterised by erratic volumetric loading rates, the plant performance for COD removal efficiency was observed to vary rapidly. During phase 3, the loading rates stabilised between $7.1 \mathrm{~kg} \mathrm{COD} / \mathrm{m}^{3}$.day and 8.2 $\mathrm{kg} \mathrm{COD} / \mathrm{m}^{3}$.day, and the removal efficiencies appeared to be stable. Apparently, the removal efficiency increased steadily beyond $80 \%$, which is within the expected removal efficiency for the distillery wastewater generated from grape-based feedstock. In experimental run II, the average loading rate was approximately $6.20 \mathrm{~kg} \mathrm{COD} / \mathrm{m}^{3}$.day.

The process stability was also monitored as a function of $\mathrm{pH}$ variation. The performance of the UASB reactor in terms of COD removal efficiency as a function of the $\mathrm{pH}$ is shown in Figure 5. Gentle variation in the $\mathrm{pH}$ from 6 to 7 had a positive effect on the COD removal efficiency, which was observed to have increased linearly from approximately $30 \%$ to around $70 \%$. This is because, within this $\mathrm{pH}$ range, the reactor contained optimal conditions for the growth and activity of methane-producing bacteria (Mudrak and Kunst, 1986). However, a sudden increase of the $\mathrm{pH}$ to alkaline conditions of around 8 , followed by a sudden reduction into acidic conditions to a $\mathrm{pH}$ of about 6 , caused the granules to be unstable, as evidenced by the erratic changes in the COD removal

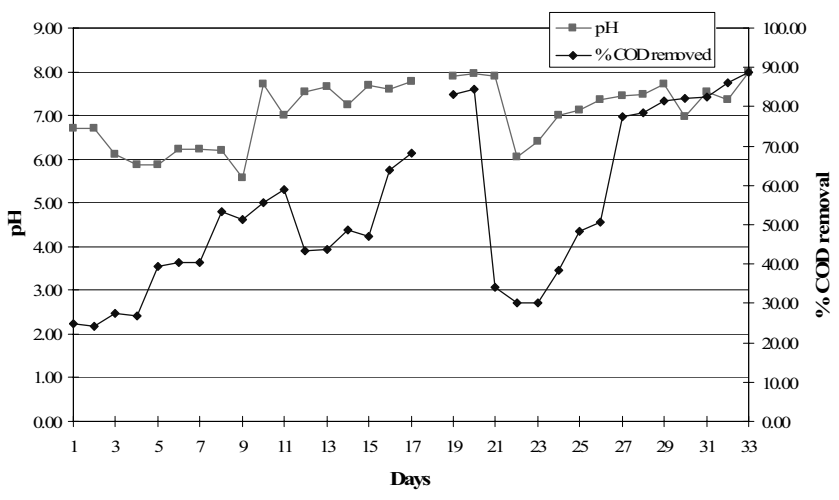

FIGURE 5

$\mathrm{pH}$ variations vs. COD removal efficiencies under experiment II. efficiencies. After day 26, when the $\mathrm{pH}$ stabilised at about 7 , the system recovered and reactor performance increased to the expected levels for a UASB reactor of above $80 \%$.

\section{Performance of the aerobic biological reactor}

The effluent that had previously been treated using the UASB reactor was further treated using an aerobic treatment system. The aerobic degradation experiments on the effluent were performed in an activated sludge system, as described in the aerobic biological treatment sub-section. Several experiments were performed to examine further reduction of the organic matter using the aerobic treatment. In this case study, we present the results where the effluent concentration in the aerobic treatment system after treatment in the UASB reactor was $1035 \mathrm{mg} / \mathrm{L}$.

Figure 6 shows a further reduction in COD for the UASB effluent using an aerobic process. The aerobic batch reactors were operated for a period of 168 hours (seven days) and the COD concentration was measured daily. The final effluent concentration after seven days was measured to be $400 \mathrm{mg} / \mathrm{L}$, as opposed to the initial influent concentration of $1035 \mathrm{mg} / \mathrm{L}$. In effect, the aerobic process had an efficiency of $61.8 \%$ in removing the COD from the effluent. Thus, the combined effect that was achieved by treating the effluent through sequencing the anaerobic and aerobic treatment stages in this case was $96.5 \%$. It should be noted that, owing to the high combined removal efficiency of the organic matter using both anaerobic and aerobic systems, the final effluent was found to meet the stringent legislative requirements for effluent disposal through irrigation in South Africa.

Similarly, in the case of phosphorous, its concentration was monitored for seven days (see Figure 6). As can be seen, the initial and final concentrations were $75 \mathrm{mg} / \mathrm{L}$ and $20 \mathrm{mg} / \mathrm{L}$, respectively. After treating the effluent using the aerobic process, phosphorous in the effluent was reduced by $73.3 \%$. However, the phosphorous concentrations in the effluent from the aerobic system were higher than the stipulated South African limits of $10 \mathrm{mg} / \mathrm{L}$ that are acceptable for discharge into surface waters (Müller, 1999). It should be noted that, although it appears that the phosphorous regulatory limits (see Figure 6) can be achieved by treating the effluent under aerobic treatment conditions for an extended period, this approach has practical limitations. Therefore, future work should focus on improving the design specifications of the aerobic system in order to achieve phosphorous removal from the distillery effluent within a reasonably short period of time that can be practical in actual effluent treatment plants.

A significant increase in effluent $\mathrm{pH}$ was observed during the aerobic experiments. On average, the $\mathrm{pH}$ increased to 8.2 because of the drop in phosphate concentrations in the effluent. This was because of further precipitation of phosphate minerals under the $\mathrm{pH}$ of higher than 8 in the volumetric flasks.

Figure 7 depicts the removal of gallic acid from the effluent after the UASB treatment. The high concentration of gallic acid in the effluent is due to the presence of phenolics, as the distillery feedstock used was grapes. The presence of gallic acid in the effluent renders it acidic and hence makes it unsuitable for irrigational purposes. This is mainly because this effluent has a high potential to render the receiving soils acidic. From Figure 7 it is evident that the aerobic process was very effective in reducing the phenolics in comparison to the anaerobic process. For instance, the former process reduced the gallic acid from $150 \mathrm{mg} / \mathrm{L}$ to $20 \mathrm{mg} / \mathrm{L}$ in 72 


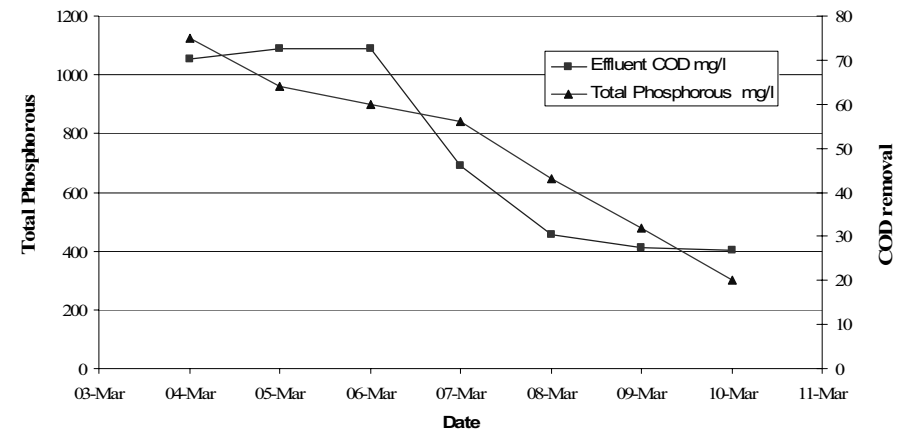

FIGURE 6

Reduction of phosphorous and COD through the aerobic treatment process.

hours, while the latter insignificantly decreased the acid concentration to $110 \mathrm{mg} / \mathrm{L}$ over the same period. Although it may appear that the best approach for achieving a further reduction in phosphorous and gallic acid concentrations in the effluent is having longer retention periods during the aerobic process, this is not feasible in practice due the design limitations of the aerobic system. However, from a practical point of view, an effective reduction in phosphorous and gallic acid concentrations in the distillery effluent is possible if the aerobic sludge system design is optimised.

\section{CONCLUSIONS}

In this paper, it was demonstrated that, on the laboratory scale, sequencing the UASB effluent treatment reactor and an aerobic treatment process provides an enhancement in COD removal from distillery effluent. Owing to the hybrid (anaerobic/aerobic) system of effluent treatment, an overall COD removal efficiency of $96.5 \%$ was achieved. These results are similar and better than the results of just over $90 \%$ previously reported by Wolmarans and De Villiers (2002), who used a single UASB treatment without any form of post-treatment of the effluent. Moreover, the results also show that the aerobic process enhances the removal of phosphorous and gallic acid from distillery effluent. Notably, the findings presented in this article for phosphorous and gallic acid removal were achieved by extending the retention time for up to seven days during the aerobic effluent treatment process, although this approach may be unfeasible in actual aerobic sludge digesters. It is therefore recommended that the design of the aerobic sludge system be optimised, and that the concentrations of these variables in the sludge during the actual plant operations are monitored effectively.

\section{LITERATURE CITED}

APHA, 1995 (19th ed). Standard Methods for the Examination of Water and Wastewater. American Public Health Association, Washington, DC.

Calderon, D.G., Buffiére, P., Moletta, R. \& Elmaleh, S., 1998. Anaerobic digestion of winery distillery wastewater in down-flow fluidized bed. Water Res. 32(12), 3593-3600.

Chapman, J., Baker, P. \& Wills, S., 2001. Winery Wastewater Handbook: Production, Impacts and Management. Winetitles, Adelaide, Southern Australia.

Danfonchio, D., Colombo, M., Origgi, G., Sorlini, C. \& Andreoni, I., 1998. An integrated digestion of winery wastewaters derived from different wine making processes. J. Environ. Sci. and Health, Part A: Toxic/Hazardous Subst. and Environ. Eng. 33, 1758-1770.

Driessen, W.J.M.B., Tielbaad, M.H. \& Vereijken T.L.F.M., 1994. Experience on anaerobic treatment of distillery effluent with the UASB process. Proc. 7th Int. Symp. Anaer. Digest., Cape Town, South Africa. pp. 253 - 262.

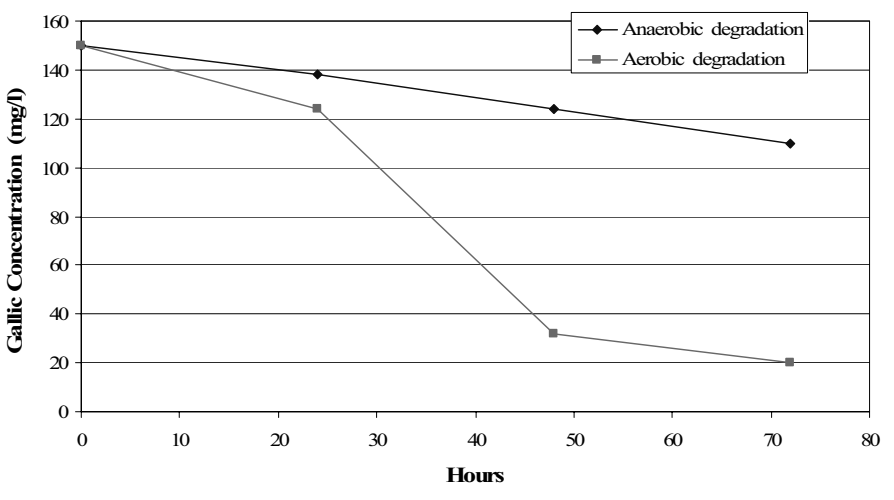

FIGURE 7

Comparison of the efficacy of gallic acid removal using aerobic and anaerobic processes.

Eremektar, G., Babuba, G.F. \& Ince, O., 1999. Fate of inert COD fractions in twostage biological treatment of a strong wastewater, J. Environ. Sci. and Health, Part A: Toxic/Hazardous Subst. and Environ. Eng. 34(6), 1329-1340.

García-Bernet, D., Buffière, P., Elmaleh, S. \& Moletta, R., 1998. Application of the down-flow fluidized bed to the anaerobic treatment of wine distillery wastewater. Wat. Sci. Technol. 38(8-9), 393-399.

Goodwin, J.A.S. \& Stuart, J.B., 1994. Anaerobic digestion of malt whiskey distillery pot ale using up-flow anaerobic sludge blanket reactors. Bioresour. Technol. 49(1), 75-81.

HulshoffPol, L.W., 1989. The phenomenon of granulation of anaerobic sludge. Thesis, Agricultural University of Wageningen, P.O. Box 9101, 6700 HB Wageningen, The Netherlands.

Malandra, L., Wolfaardt., G. Zietsman, A. \& Viljoen-Bloom, M., 2003. Microbiology of a biological contactor for winery wastewater treatment. Water Res. 37, 4125-4134.

Marais, D., 2001. The development of an audit procedure and treatment technologies for Rupert and Rothschild Vignerons' winery wastewater. Thesis, Department of Process Engineering, University of Stellenbosch, Private Bag X1, 7602 Matieland (Stellenbosch), South Africa.

Moosbrugger, R.E., Wentzel, M.C., Ekama, G.A. \& Marais, G.v.R., 1993. Treatment of winery waste in UASB systems - feasibility, alkalinity requirements and $\mathrm{pH}$ control. Water Sci. Technol. 28(2), 45-54.

Mudrak, K. \& Kunst, S., 1986. In: Biology of Sewage Treatment and Water Pollution Control. Ellis Horwood Ltd, England. p. 193.

Müller, A.M., 1999. Government of South Africa Gazette No. 20526.8, October, 1999. Government Notice, Department of Water Affairs and Forestry, Section 21 (e).

Müller, D., 1994. Cleaning wastewater by a rotation system. In: Recault, Y. (ed). Proc. 2nd Inter. Specialized Conf. Winery Wastewaters, June 1994, Narbonne, France. pp. $103-109$.

Petruccioli, M., Duarte, J.C. \& Federici, F., 2000. High rate anaerobic treatment of winery wastewater using bioreactors with free and immobilized activated sludge. J. Biosci. Bioeng. 90(4), 381-386

Petruccioli, M., Duarte, J.C., Eusebio, A. \& Federici, F., 2002. Aerobic treatment of winery wastewater using jet-loop activated sludge reactor. Proc. Biochem. 37, $821-829$.

Rankine, B., 1989. Making Good Wine: A Manual of Winemaking Practice for Australia and New Zealand. Sun Books, South Melbourne, Australia.

Shepherd, H.L., 1998. Performance evaluation of a pilot scale constructed wetland used for treatment of winery process wastewater. In: Recault, Y. (ed). Proc. 2nd Specialized Conf. on Winery Wastewaters, May 5-7 1998, Bordeaux, France. pp. $155-163$.

Shepherd, H.L., Grismer, M.E. \& Tchobanoglous, G., 2001. Treatment of highstrength winery wastewater using subsurface flow constructed wetland. Water Environ. Res. 73, 394-402.

Wentzel, M.C., Dold, P.L., Ekama, G.A. \& Marais, G.v.R., 1985. Kinetics of biological phosphorus release. Water Sci. Technol. 17, 57-71.

Wolmarans, B. \& De Villiers, G.H., 2002. Start-up for a UASB effluent treatment on distillery wastewater. Water SA 28, 63-68. 